\title{
Character Association and Path Analysis of Fennel (Foeniculum vulgare Mill.) Varieties in Rayalaseema Region of Andhra Pradesh
}

\author{
Ashfaq Anvarbadashalladli*, K. M. Yuvaraj, R. Srinivasulu, \\ M. Jayaprada and Y. Deepthi Kiran
}

Department of Plantation, Spice, Medicinal and Aromatic Crops, College of Horticulture, Dr. Y.S.R. Horticultural University, Anantharajupeta, Railway Kodur, Mandal, Kadapa District, Andhra Pradesh, India

*Corresponding author

Keywords

Correlation, Path analysis, Fennel, Seed yield, Andhra Pradesh

\section{Article Info}

Accepted:

25 November 2020 Available Online: 10 December 2020

\section{A B S T R A C T}

In the present investigation, sixteen fennel varieties were evaluated in the Department of Plantation, Spices, Medicinal and Aromatic Crops at the College of Horticulture, Anantharajupeta, Dr. Y.S.R. Horticultural University, Dr. Y.S.R. Kadapa District of Andhra Pradesh during Rabi season, 201920.Association studies revealed that, six characters viz., number of umbels per plants, harvest index, umbels per umbel, seeds per umbel, dry weight of umbel and primary branches per plant exhibited significantly positive correlation at both genotypic and phenotypic level, while days to first flowering and days taken to 50 percent flowering were the traits those attained negative significant correlation at both levels with seed yield per plant. Path analysis indicated that harvest index, primary branches per plant, seeds per umbel and dry weight of umbel have positive direct effect while, days to 50 per cent flowering has negative direct effect on seed yield per plant. Hence, these traits in desirable direction could be relied upon for selection of varieties in order to improve genetic yield potential of fennel varieties.

\section{Introduction}

The importance of fennel is well realized on account of its high remunerative prices, domestic consumption, medicinal value and means to get earn foreign exchange. Despite the economic importance of fennel, disease resistant, locally acceptable and high yielding crop. The present investigation was therefore, carried out to estimate the association of yield traits on the seed yield per plant in which a breeder can predict the extent of dependence on important traits on phenotypic selection for improvement of traits. The analysis of 
variance revealed that significant amount of variability was present in germplasm lines for all the traits under study viz., plant height, primary branches per plant, secondary branches per plant, days to 50 percent flowering, days to maturity, umbels per plant, umbellets per umbel, seeds per umbel, and seed yield per plant. A wide range of mean for yield and some of its contributing traits indicates good chance for improvement of yield through direct selection or by transferring desired traits. Correlation analysis provides information on the extent of relationship between different characters. This relationship among the yield contributing characters and seed yield provides information whether the characters are associated positively or negatively with one and all and also the magnitude of relationship, so that selection for increased seed yield can be made indirectly through the positively associated other characters.

Selection based on seed yield is quite not reliable, as yield is a complex quantitative trait that is governed by polygenes and also highly influenced by environmental factors in which the crop is grown. So, selection of secondary traits associated with this complex trait is a way to achieve higher grain yield. Correlation analysis used as effective tool to determine the relationship among different traits in genetic diverse population for enhancement of crop improvement process. As more variables are included in the correlation study, the association become more complex. In such a situation, the path coefficient analysis provides an effective means of finding out direct and indirect causes and effects of association and permits a critical examination of the specific forces acting to produce a given correlation and measures the relative importance of each factor. Thus, aim of this study was to find out potential secondary traits associated with seed yield through correlation and path analysis.

\section{Materials and Methods}

The experiment was conducted in an open field condition located at College of Horticulture, Anantharajupeta in Southern Agro Climatic Zone of Rayalaseema region in Andhra Pradesh. The experimental site is located at an altitude of $162 \mathrm{~m}$ (531 feet) above mean sea level lying between the $130.59^{\circ}$ North latitude and $790.19^{\circ}$ East longitude.

The experimental material consists of sixteen genotypes of fennel in randomized block design with three replications. Each genotype is planted at a spacing of $50 \mathrm{~cm} \times 20 \mathrm{~cm}$. The pooled data on fifteen yield and yield attributing traits was taken randomly in five plants and tagged all three replications to record the pooled data and analyzed by the standard statistical methods.

\section{Results and Discussion}

Genotypic and phenotypic correlations were worked out among different characters including seed yield. The phenotypic correlation coefficient was generally higher than the respective genotypic correlation coefficient.

Phenotypic correlation coefficient provides a measure of genetic association between characters and thus, help in identifying the traits which need to be considered for improvement of yield. Since, suitable test for significance of phenotypic correlations is not available so their main usefulness is in strengthening the interpretations based on genotypic correlations.

Phenotypic and genotypic associations were carried out for all traits under study to reveal the association of seed yield per plant with other yield causative traits and shown in Table.3 (Fig 1) and Table.4 (Fig 2) respectively. 
The number of seeds per umbel (0.752), the number of umbellet per umbel (0.709), the number of seeds per umbellet (0.662) at phenotypic level had a highly important and positive association with plant height $(\mathrm{cm})$. The number of secondary branches (0.316), days to maturity (0.520), number of umbels per plant (0.483) and seed yield per plant were also positive and significantly correlated with this character (0.403). Negative nonsignificant association of plant height was found with test weight (-0.196) and days to 50 percent flowering (-0.021).

At genotypic stage, plant height showed positive association with days to maturity (0.932) followed by seeds per umbellet (0.835).Negative and non significant association was observed with days to 50 per cent flowering (-0.196) and test weight (0.152). These findings corroborated with the earlier findings viz., Yadav et al., (2013) and Garg et al., (2003).

At the phenotypic level, primary branches per plant had a highly substantial positive association with secondary branches (0.836). Furthermore, this character has shown a clear positive correlation with the number of umbels per plant (0.720), the dry weight of the plant at harvest (0.708), the yield of the seeds per plant (0.697), harvest index (0.435), the seeds per umbellet (0.421), seeds per umbellet (0.383), number of umbellets per umbel (0.378), and dry weight of the umbel (0.358). But this character had a non-significant negative association with the days to first flowering (0.228).At the genotypic stage, the primary branches showed a significant positive connotation with the secondary branches per plant (0.940), followed by the dry weight of the plant at harvest $(0.795)$, the seed yield per plant (0.786), Contradictory to this, Cosge et al., (2009), and Jeeterwal et al., (2015) reported a positive and significant relationship with seed yield per plant for plant height and branches per plant, while Yadav et al., (2013) reported a positive and substantial relationship with seed yield per plant, branches per plant and plant height.

The secondary branches per plant was extremely significant and positively associated with umbels per plant (0.753) followed by the phenotypic amount of seed yield per plant (0.689) and dry weight of the plant at harvest (0.680).At genotypic level secondary branches was correlated significantly positive with plant dry weight at harvest $(0.814)$ followed by seed yield per plant (0.808), number of umbels per plant (0.770) and number of umbellets per umbel (0.566). The correlation of days taken to flowering $(-0.374)$ was found negatively significant.

Days taken to blossoming was found to be correlated positively with test weight $(0.144)$ and dry weight of plant at harvest $(0.120)$, days to 50 per cent blossoming (0.044) but non significant at phenotypic level. The correlation of days taken to flowering with harvest index, (-0.421), number of umbellets per umbel $(-0.344)$, seed yield per plant (0.324 ) and number of umbels per plant (0.307 ) was found negatively significant. At genotypic level, days taken to flowering days was correlated significantly positive with days to $50 \%$ flowering (0.441) and days to maturity (0.432). Days to 50 percent flowering had a highly important and significant association with plant dry weight at harvest (0.358) followed by harvest index (0.309) at phenotypic level and negative association with days to maturity (-0.165), number of seeds per umbel $(-0.126)$ and number of seeds per umbellet (-0.046).

At genotypic level, days to 50 per cent blossoming was found to be highly significant positive connotation with dry weight of plant at harvest (0.620) But this character had negative significant connotation with days to 
maturity (-0.720) followed by number of seeds per umbellet (-0.310).Days to maturity was correlated significantly positive with number of seeds per umbellet (0.385) followed by number of seed per umbel (0.344) and number of umbellets per umbel (0.314) at phenotypic level. Harvest index (-0.189) and test weight (0.133 )was found negative but non-significant with this character. At genotypic level, days taken to maturity was found to be correlated positive and highly significant with plant height (0.932) followed by number of umbellets per umbel (0.691) and number of seeds per umbel (0.628) but negatively substantial with harvest index (-0.345) after that test weight $(-0.320)$. Number of umbels per plant was found to be correlated positive and highly significantly with seed yield per plant (0.868) followed by number of umbellets per umbel (0.684) and number of seeds per umbel (0.763). This trait had negative nonsignificant association with test weight (0.027).

At genotypic level, number of umbels per plant showed significant positive association with seed yield per plant (0.945) followed by number of umbels per plant (0.869) while, it is negatively significant with days taken to flowering (-0.440).Number of umbellets per umbel showed significant positive correlation with all the characters studied excluding for the test weight $(-0.027)$, which is negatively non-significant at phenotypic level. Highest positive significant was found with number of seeds per umbel (0.931) followed by number of umbellets per umbel (0.708) and harvest index (0.567).At genotypic level, the umbellets per umbel showed positive correlation with number of seeds per umbellet (0.988) and number of seeds per umbellet (0.848). While, it is negatively significant with days taken to flowering (-0.410).

The number of seeds per umbel had positive association with the number of seeds per umbel (0.836), followed by seed yield per plant (0.518) and harvest dry weight (0.466). These results are similar to Sharma et al., (2015).At the genotypic stage, the number of seeds per umbel had a significant positive relationship with seeds per umbel (0.968) and number of umbellets per umbel (0.848). These results are similar to Sharma et al., (2015).

There was a strong positive connotation between the number of seeds per umbel and the seed yield per plant (0.713), followed by the harvest index (0.516) and dry weight of the plant at harvest $(0.506)$ at the phenotypic stage. This character had a negative nonsignificant connection with test weight ($0.065)$. These results are in conjunction with Kumar et al., (2017) and Sefidan et al., (2014).At genotypic level this character showed positive significant correlation with primary branches per plant (0.445).Remaining characteristics were correlated in a favorable, non-significant way and negatively interrelated with the days of first flowering ($0.350)$. These findings are in accordance with Kumar et al., (2017) and Sefidan et al., (2014).

Dry weight of umbel had highly significant positive relationship with seed yield per plant (0.700) and harvest index (0.592) and negative but non-significant correlation was found with test weight $(-0.122)$ at phenotypic level. At genotypic level, the dry weight of umbel had positively significant association with seed yield per plant (0.827) and harvest index (0.818) while, it is negatively non significant with days taken to flowering (-0.258) and days to maturity (-0.048). Dry weight of plant at harvest showed highly positive significant connotation with seed yield per plant (0.630) followed by harvest index (0.357) at phenotypic level. Remaining traits had positive non-significant association with this character and it had negatively non-significant association with test weight (-0.098).At 
genotypic level, dry weight of plant at harvest disclosed significant positive connotation with secondary branches per plant (0.814) and primary branches (0.795) while, it is negatively significant with test weight $(-0.433)$ and non significant with days to maturity (0.016). These conclusions are in accord with Sharma et al., (2015).

A highly important positive association with seed yield per plant was pragmatic for the harvest index (0.828) and umbels per plant (0.657). But this character had a strong negative association with the first flowering days $(-0.421)$.

The same findings were established by Dashora and Sastry (2011) and Meena et al., (2013).At the genotypic stage, the harvest index had a strong positive correlation with the seed yield per plant (0.847), after that the dry weight of the umbel $(0.818)$, the number of umbels per plant (0.867), seeds per umbel (0.535) and umbellets per umbel (0.528).

The test weight did not display any important association with any of the features. Positively non-significant connotation of test weight with days taken to flowering (0.143), harvest index (0.128), primary branches (0.103)and days to50 per cent flowering (0.064) were identified, and negative non-significant remaining characteristics.

At the genotypic stage, the test weight displayed negative significance with the days of maturity (-0.320), the dry weight of the plant at harvest $(-0.433)$ and the rest of all other characters.

The secondary branches per plant (0.065) followed by days to first flowering (0.075), days of fifty percent flowering (0.193), umbels per plant (0.052), dry weight of umbels (0.150) and harvest index (0.066) showed positive non-significance. A highly important positive correlation was observed for seed yield per plant with umbels per plant (0.868), followed by harvest index (0.828), umbels per umbel (0.737), seeds per umbel (0.713), dry weight of umbel (0.700) and primary branches per plant (0.697) at phenotypic stage. However, this character had a negative significant association with days taken to flowering (-0.324) and non-significant with test weight $(-0.059)$.

These conclusions corroborated the former findings of Dashora and Sastry (2011).Seed yield per plant exhibited positive significance with umbels per plant (0.945), harvest index (0.847), dry weight of umbel (0.827), secondary branches per plant (0.808), primary branches per plant (0.786), umbellets per umbel (0.744), seeds per umbel (0.726), dry weight of plant at harvest (0.700), but negatively significant with days taken to flowering (-0.380).

According to current research, the genotypic correlation was greater than their corresponding phenotypic association, suggesting that there was a clear intrinsic connection between the characters.

Seed yield per plant has been found to be substantially and positively associated with plant height, primary branches per plant, Secondary branches per plant, days to 50 per cent of flowering, days to maturity, umbels per plant, umbels per umbel, seeds per umbel, seeds per umbellet, dry weight of umbel, dry weight of the plant at harvest and harvest index.

These findings documented the earlier findings of Sharma et al., (2015), Yadav et al., (2013), Meena et al., (2013) and in fennel. On the other hand, seed yield per plant has shown significant and negative correlation with test weight and days taken to flowering at both levels. 
Table.1 Genotypic correlation coefficients $\left(r_{\mathrm{g}}\right)$ for seed yield and related traits in fennel varieties

\begin{tabular}{|c|c|c|c|c|c|c|c|c|c|c|c|c|c|c|c|}
\hline Characters & X1 & $\mathbf{X} 2$ & X3 & X4 & X5 & X6 & $\mathbf{X} 7$ & X8 & X9 & X10 & X11 & $\mathrm{X} 12$ & X13 & X14 & X15 \\
\hline X1 & 1 & & & & & & & & & & & & & & \\
\hline $\mathbf{X} 2$ & 0.255 & 1 & & & & & & & & & & & & & \\
\hline X3 & $0.325^{*}$ & $0.94 * *$ & 1 & & & & & & & & & & & & \\
\hline X4 & 0.185 & -0.251 & $-0.374 *$ & 1 & & & & & & & & & & & \\
\hline X5 & -0.196 & $0.526 * *$ & $0.497 * *$ & $0.411 *$ & 1 & & & & & & & & & & \\
\hline X6 & $0.932 * *$ & -0.168 & 0.0591 & $0.432 *$ & $-0.72 * *$ & 1 & & & & & & & & & \\
\hline $\mathbf{X} 7$ & $0.55 * *$ & $0.788^{*}$ & $0.77 * *$ & $-0.440 *$ & 0.25 & 0.078 & 1 & & & & & & & & \\
\hline $\mathbf{X 8}$ & $0.750 * *$ & $0.454^{*}$ & $0.566 * *$ & $-0.410 *$ & -0.234 & $0.691 * *$ & $0.869 * *$ & 1 & & & & & & & \\
\hline X9 & $0.835^{* *}$ & $0.328^{*}$ & $0.444 *$ & -0.095 & $-0.31^{*}$ & $0.378 *$ & $0.740 * *$ & $0.848 * *$ & 1 & & & & & & \\
\hline X10 & $0.796 * *$ & $0.445^{*}$ & $0.534 * *$ & $-0.350 *$ & -0.215 & $0.628 * *$ & $0.829 * *$ & $0.988 * *$ & $0.968 * *$ & 1 & & & & & \\
\hline X11 & 0.177 & $0.547 * *$ & $0.420 *$ & -0.258 & 0.1767 & -0.048 & $0.787 * *$ & $0.597 * *$ & $0.629 * *$ & $0.598 * *$ & 1 & & & & \\
\hline X12 & $0.447 *$ & $0.795 * *$ & $0.814 * *$ & 0.011 & $0.62 * *$ & -0.016 & $0.700 * *$ & $0.465^{* *}$ & $0.607 * *$ & $0.522 * *$ & $0.638 * *$ & 1 & & & \\
\hline X13 & 0.088 & $0.502 * *$ & $0.525^{* *}$ & $-0.51 * *$ & 0.209 & $-0.345^{*}$ & $0.867 * *$ & $0.528 * *$ & $0.427 *$ & $0.535 * *$ & $0.818 * *$ & $0.407^{*}$ & 1 & & \\
\hline X14 & -0.152 & -0.001 & 0.065 & 0.075 & 0.193 & $-0.320 *$ & 0.052 & -0.108 & -0.273 & -0.155 & 0.150 & $-0.433 *$ & 0.066 & 1 & \\
\hline X15 & $0.392 *$ & $0.786^{* *}$ & $0.808 * *$ & $-0.380 *$ & 0.260 & 0.189 & $0.945 * *$ & $0.744 * *$ & $0.614 * *$ & $0.726 * *$ & $0.827 * *$ & $0.70 * *$ & $0.847 * *$ & -0.093 & 1 \\
\hline
\end{tabular}

*significant at 5 percent level ** significant at 1 percent level

$\mathrm{X} 1=$ Plant height $(\mathrm{cm}) \quad \mathrm{X} 6=$ Days to maturity

$\mathrm{X} 2=$ Number of primary branches per plant

$\mathrm{X} 3=$ Number of secondary branches per plant

$\mathrm{X} 4=$ Days to first flowering

$\mathrm{X} 5=$ Days to $50 \%$ flowering
$X 7=$ Number of umbels per plant

$\mathrm{X} 8=$ Number of umbellets per umbel

$X 9=$ Number of seeds per umbellet

$\mathrm{X} 10=$ Number of seeds per umbel
$\mathrm{X} 11=$ Dry weight of umbel $(\mathrm{g})$

$\mathrm{X} 12=$ Dry weight of plant at harvest $(\mathrm{g})$

$\mathrm{X} 13=$ Harvest index $(\%)$

$\mathrm{X} 14=$ Test weight $(\mathrm{g})$

$\mathrm{X} 15=$ Seed yield per plant $(\mathrm{g})$ 
Table.2 Phenotypic correlation coefficients $\left(r_{p}\right)$ for seed yield and its related characters in fennel varieties

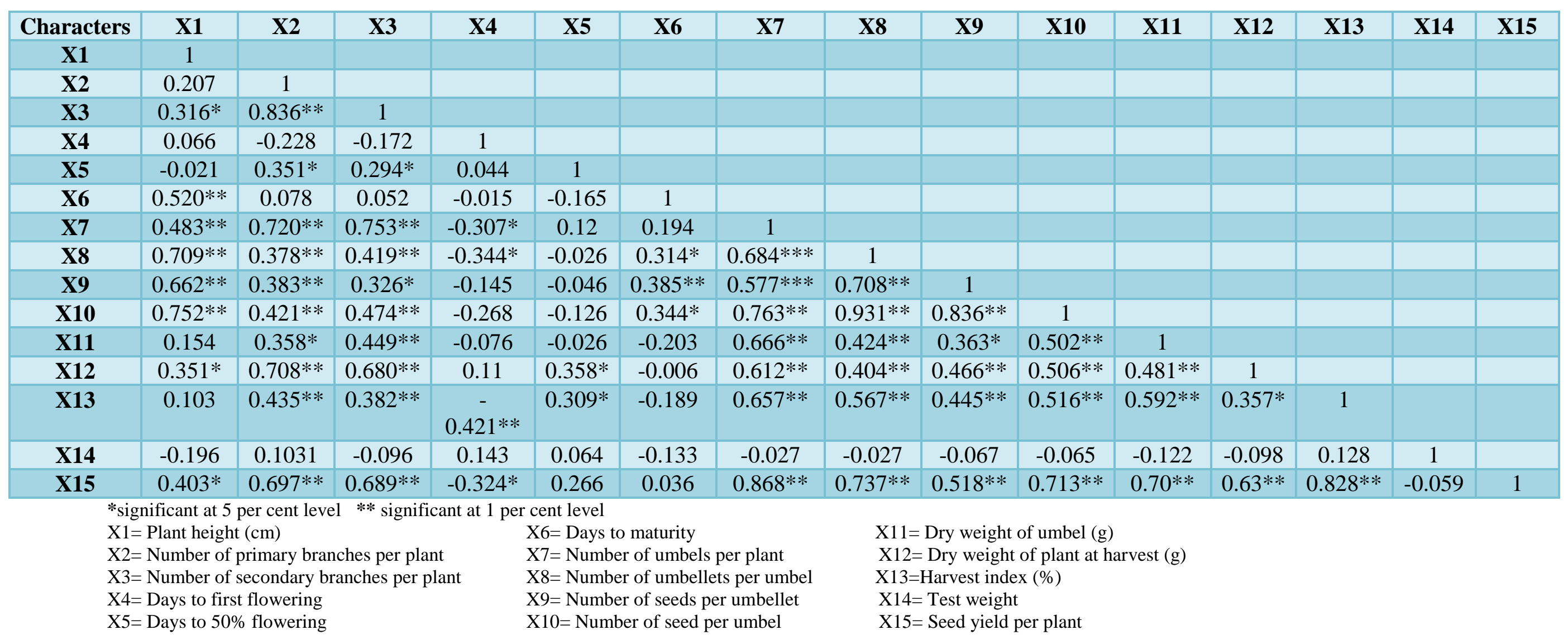


Table.3 Genotypic path analysis for seed yield per plant in fennel varieties

\begin{tabular}{|c|c|c|c|c|c|c|c|c|c|c|c|c|c|c|c|}
\hline Characters & X1 & $\mathrm{X} 2$ & X3 & $\mathrm{X} 4$ & X5 & X6 & $\mathbf{X 7}$ & X8 & X9 & X10 & X11 & $\mathrm{X} 12$ & X13 & X14 & rg \\
\hline X1 & 0.058 & 0.0148 & 0.0188 & 0.0107 & -0.011 & 0.0589 & 0.0305 & 0.0435 & 0.0484 & 0.0461 & 0.0103 & 0.0259 & 0.0051 & -0.0088 & $0.392 *$ \\
\hline $\mathbf{X} 2$ & 0.2315 & 0.9076 & 0.9501 & -0.2284 & 0.4772 & -0.153 & 0.7152 & 0.4123 & 0.2973 & 0.4043 & 0.4968 & 0.7213 & 0.456 & -0.0014 & $0.786 * *$ \\
\hline $\mathbf{X 3}$ & -0.1019 & -0.3284 & -0.3137 & 0.1172 & -0.155 & -0.0185 & 0.2439 & -0.1775 & -0.1392 & -0.1675 & -0.1318 & -0.2553 & -0.1647 & -0.0204 & $0.808 * *$ \\
\hline X4 & 0.0464 & -0.0631 & -0.0937 & 0.2507 & 0.1031 & 0.1084 & -0.1121 & -0.1039 & -0.024 & -0.0891 & -0.0648 & 0.0029 & -0.1279 & 0.0188 & $-0.387^{*}$ \\
\hline X5 & 0.0094 & -0.0253 & -0.0239 & -0.0198 & -0.048 & 0.0359 & -0.0121 & 0.0113 & 0.0152 & 0.0104 & -0.0085 & -0.03 & -0.0101 & -0.0093 & 0.26 \\
\hline X6 & -0.0049 & 0.0008 & -0.0003 & -0.0021 & 0.0036 & -0.0049 & -0.0004 & -0.0034 & -0.0018 & -0.003 & 0.0002 & 0.0001 & 0.0017 & 0.0016 & 0.189 \\
\hline $\mathbf{X} 7$ & -0.0418 & -0.0627 & -0.0618 & 0.0356 & -0.019 & -0.0062 & -0.0795 & -0.0691 & -0.0588 & -0.0659 & -0.0626 & -0.0557 & -0.069 & -0.0041 & $0.945 * *$ \\
\hline X8 & 0.2835 & 0.1718 & 0.214 & -0.1567 & -0.088 & 0.2614 & 0.3286 & 0.3782 & 0.3207 & 0.3739 & 0.2256 & 0.1757 & 0.1998 & -0.041 & $0.744 * *$ \\
\hline X10 & 0.1791 & 0.1003 & 0.1202 & -0.08 & -0.048 & 0.1414 & 0.1866 & 0.2226 & 0.2179 & 0.2252 & 0.1346 & 0.1176 & 0.1204 & -0.0349 & $0.726 * *$ \\
\hline X11 & 0.0342 & 0.1052 & 0.0808 & -0.0497 & 0.034 & -0.0092 & 0.1514 & 0.1147 & 0.121 & 0.1149 & 0.1923 & 0.1227 & 0.1572 & 0.0289 & $0.827 * *$ \\
\hline X12 & -0.1106 & -0.1967 & -0.2015 & -0.0029 & -0.154 & 0.0038 & -0.1732 & -0.115 & -0.1502 & -0.1293 & -0.1579 & -0.2475 & -0.1007 & 0.1071 & $0.706^{* *}$ \\
\hline X13 & 0.0474 & 0.2703 & 0.2824 & -0.2744 & 0.1127 & -0.1853 & 0.4664 & 0.2841 & 0.2298 & 0.2877 & 0.4398 & 0.2189 & 0.538 & 0.0356 & $0.847 * *$ \\
\hline X14 & 0.039 & 0.0004 & -0.0166 & -0.0192 & -0.049 & 0.082 & -0.0133 & 0.0277 & 0.0699 & 0.0397 & -0.0385 & 0.1108 & -0.0169 & -0.2559 & -0.093 \\
\hline X15 & $0.392 * *$ & $0.786^{* * *}$ & $0.808 * *$ & $-0.387 *$ & 0.261 & 0.189 & $0.945^{* *}$ & $0.744 * *$ & $0.614^{* *}$ & $0.726 * *$ & $0.827 * *$ & $0.706^{* *} *$ & $0.847 * *$ & -0.093 & 1 \\
\hline
\end{tabular}

Residual effect: $0.0454,{ }^{*}$ Significant at 5 percent level and $* *$ Significant at 1 percent level

Diagonal values are direct effects; above and below diagonal are indirect effects

$r_{\mathrm{g}}$ : Genotypic correlation coefficients for seed yield per plant

$\mathrm{X} 1=$ Plant height $(\mathrm{cm}) \quad \mathrm{X} 6=$ Days to maturity

$\mathrm{X} 2=$ Number of primary branches per plant

$\mathrm{X} 3=$ Number of secondary branches per plant

$\mathrm{X} 4=$ Days to first flowering

$\mathrm{X} 5=$ Days to $50 \%$ flowering
$\mathrm{X} 7=$ Number of umbels per plant

$\mathrm{X} 8=$ Number of umbellets per umbel

$X 9=$ Number of seeds per umbellet

$\mathrm{X} 10=$ Number of seed per umbel
X11 $=$ Dry weight of umbel (g)

$\mathrm{X} 12=$ Dry weight of plant at harvest $(\mathrm{g})$

$\mathrm{X} 13=$ Harvest index $(\%)$

$\mathrm{X} 14=$ Test weight

$\mathrm{X} 15=$ Seed yield per plant 
Table.4 Phenotypic path analysis for seed yield per plant in fennel varieties

\begin{tabular}{|c|c|c|c|c|c|c|c|c|c|c|c|c|c|c|c|}
\hline Characters & X1 & $\mathbf{X} 2$ & X3 & $\mathrm{X} 4$ & X5 & X6 & X7 & X8 & X9 & X10 & X11 & X12 & X13 & X14 & rp \\
\hline X1 & 0.169 & 0.035 & 0.0534 & 0.0113 & 0.003 & .0879 & 0.0817 & 0.1199 & 0.112 & 0.1272 & 0.0262 & 0.0593 & 0.0175 & -0.033 & $0.403^{*}$ \\
\hline $\mathbf{X} 2$ & 0851 & 0.4111 & 0.3437 & -0.093 & 1443 & .0324 & 0.2961 & 57 & & 32 & 72 & 0.2911 & 0.1791 & 0.0424 & $7 * *$ \\
\hline X3 & 0083 & -0.022 & -0.0263 & 0045 & -0.007 & -0.001 & -0.0198 & -0.011 & -0.008 & -0.0125 & 0.011 & -0.017 & -0.01 & 0.0025 & \\
\hline X4 & 0046 & -0.0158 & -0.0119 & 0.0692 & 0.003 & 0.000 & -0.0213 & -0.0238 & -0.01 & -0.0186 & -0.005 & 0.0077 & -0.029 & 0.0099 & $-0.324^{*}$ \\
\hline X5 & .0006 & -0.0095 & -0.008 & -0.001 & -0.027 & 0.0045 & -0.0 & 0.0007 & 0.0013 & 0.0 & 0.0 & 0.0 & -0 . & -0.001 & 66 \\
\hline X6 & 051 & 0.0077 & 0.0051 & -0.001 & -0.016 & 0.098 & 0.019 & 0.0308 & 0.0378 & 0.0338 & -0.01 & 0.000 & -0.018 & -0.013 & 0.036 \\
\hline X7 & .0441 & -0.0657 & -0.0688 & 0.0281 & -0.011 & -0.017 & -0.0913 & -0.0624 & -0.052 & -0.069 & -0.06 & -0.055 & -0.06 & 0.0025 & $0.868 * *$ \\
\hline X8 & 1047 & 0.0558 & 0.0619 & -0.05 & -0.003 & 0.0464 & 0.1009 & 0.1475 & 0.1044 & 0.1373 & 0.0626 & 0.0596 & 0.0837 & -0. & $0.737 * *$ \\
\hline X9 & -0.2397 & -0.1388 & -0.118 & 0.0527 & 0.0168 & -0.135 & -0.209 & -0.256 & -0.361 & -0.3026 & -0.131 & -0.168 & -0.161 & 0.0246 & $0.518 * *$ \\
\hline X10 & 0.145 & 0.0812 & 0.0914 & -0.051 & -0.024 & 0.0664 & 0.1472 & 0.1795 & 0.1613 & 0.1927 & 0.0968 & 0.0976 & 0.0995 & -0.012 & $0.713 * *$ \\
\hline X11 & 294 & 0.0679 & & -0.014 & -0.005 & -0.038 & & 0.0805 & 0.0689 & & & 0.0913 & 0.1124 & -0.023 & $0.701 * *$ \\
\hline $\mathrm{X} 12$ & 0158 & 0.0319 & 0.0307 & 0.005 & 0.0161 & 0 & 0.0276 & 0.0182 & 0.021 & 0.0228 & 0.0217 & 0.0451 & 0.0161 & -0.004 & $0.634 * *$ \\
\hline X13 & 0.0646 & 0.2716 & 0.2383 & -0.262 & 0.1932 & -0.118 & 0.4102 & 0.3537 & 0.2777 & 0.3219 & 0.3695 & 0.2226 & 0.6235 & 0.0802 & $0.828 * *$ \\
\hline X14 & 0.0255 & -0.0133 & 0.0124 & -0.018 & -0.008 & 0.0173 & 0.0036 & & & & & 0.0127 & -0.016 & -0.129 & -0.0598 \\
\hline X15 & $0.403^{*}$ & $0.697 * *$ & $0.689 * *$ & $-0.324 *$ & 0.266 & 0.036 & $0.868 * *$ & $0.737 * *$ & $0.518^{* *}$ & $0.713 * *$ & $0.701 * *$ & $0.634 * *$ & $0.828 * *$ & -0.0598 & 1.000 \\
\hline
\end{tabular}

$*$ Significant at 5 per cent level and $* *$ Significant at 1 per cent level

Residual effect: 0.158, Diagonal values are direct effects; above and below diagonal are indirect effects

$r_{n}$. correlation coefficients for seed yield per plant

$\mathrm{X} 1=$ Plant height $(\mathrm{cm})$

$\mathrm{X} 6=$ Days to maturity

$\mathrm{X} 7=$ Number of umbels per plant

$\mathrm{X} 8=$ Number of umbellets per umbel

$\mathrm{X} 9=$ Number of seeds per umbellet

$\mathrm{X} 10=$ Number of seed per umbel
$\mathrm{X} 11=$ Dry weight of umbel $(\mathrm{g})$

$\mathrm{X} 12=$ Dry weight of plant at harvest $(\mathrm{g})$

$\mathrm{X} 13=$ Harvest index $(\%)$

$\mathrm{X} 14=$ Test weight $(\mathrm{g})$

$\mathrm{X} 15=$ Seed yield per plant $(\mathrm{g})$ 
Fig.1 Genotypic path diagram for seed yield per plant (g)Residual effect 0.045

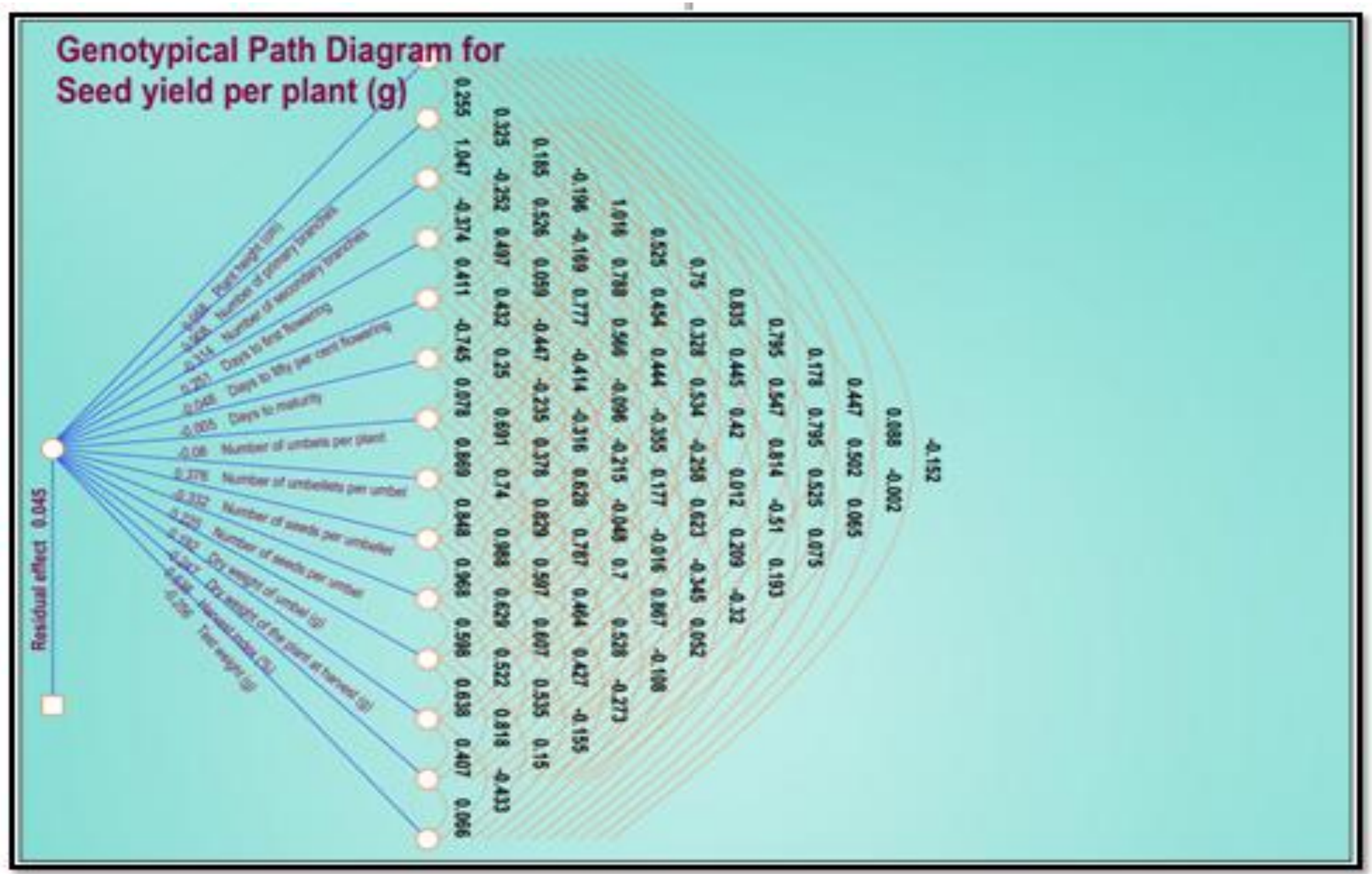


Fig.2 Phenotypic Path diagram for seed yield per plant Residual effect 0.158

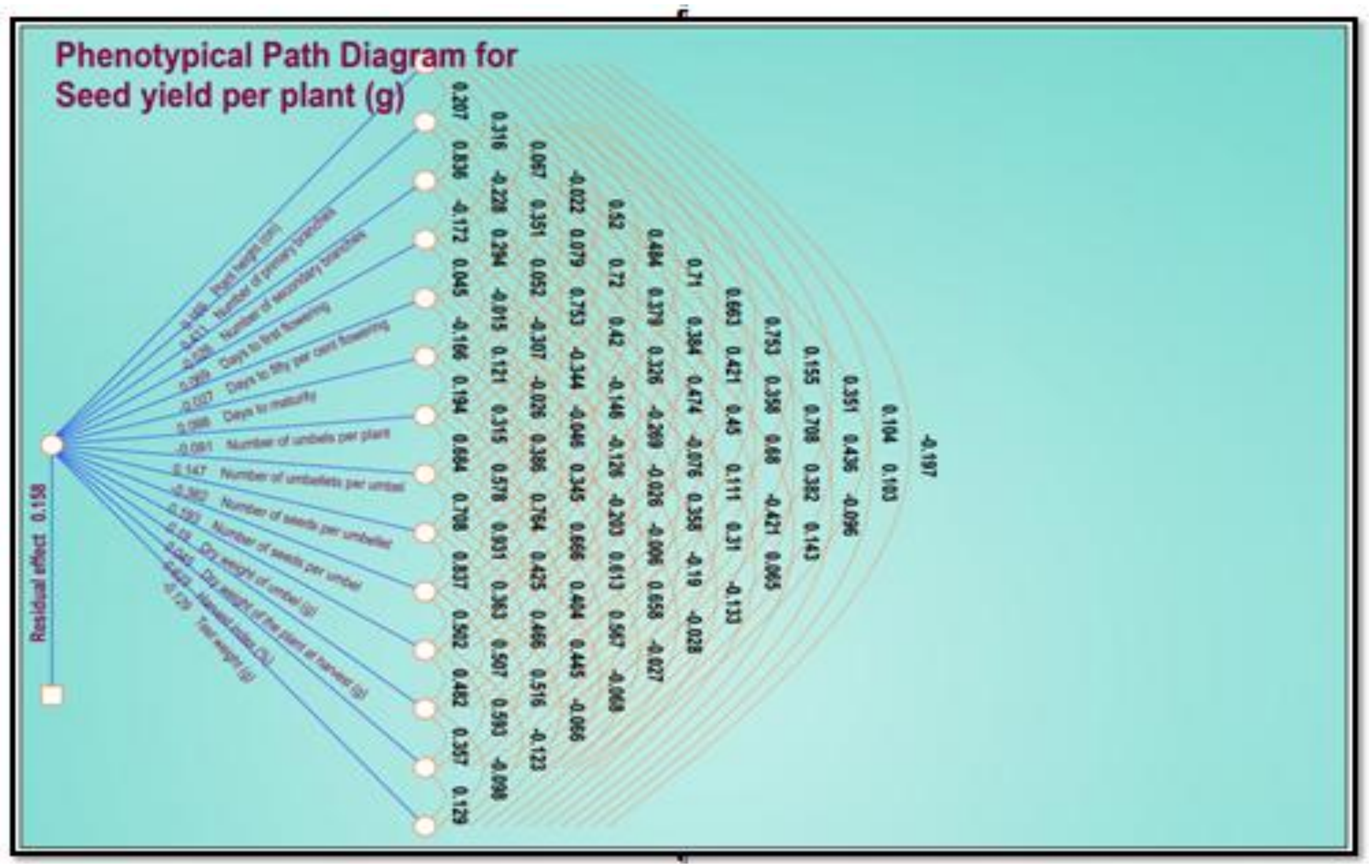


Character association is a helping hand to study the interdependence among traits and quite useful to chalk out the component traits in connection with the target descriptor i.e., seed yield per plant. The genotypic and phenotypic correlations among the traits studied pointed out the existence of statistically significant relationships among them. The higher value of genotypic correlation coefficients than that of phenotypic correlation coefficients for most of the character combinations indicated the strong inherent association between the characters, which is largely governed by genetic causes and less affected by the environment.

\section{Path analysis for various traits}

Simple correlation coefficients indicate association between any two characters but does not give a complete picture of complex relationship. Therefore, it is essential to have path coefficient analysis in order to get clear picture of association among characters, as it splits the correlation coefficient into the measure of direct and indirect effects of a set of independent variables (characters) on the dependent variable through other component traits.

The direct and indirect possessions of various characters along with their genotypic correlation coefficients with seed yield per plant are presented in Table 3. Under present study, path coefficients were analyzed by taking seed yield per plant as dependent character and remaining fourteen characters viz., plant height, primary branches per plant, secondary branches per plant, days taken to blossoming, days to 50 per cent blossoming, days to maturity, umbels per plant, umbellets per umbel, number of seeds per umbellet, number of seeds per umbel, dry weight of umbel, dry weight of plant at harvest, harvest index and test weight as independent variables.

\section{Direct effect}

In the sagacity that it does not shed light on the primary causes that are working for the various interrelations between traits, the information given by correlation analysis is deemed incomplete. In dividing the correlation coefficient into straight and ancillary results, path analysis, which is essentially a generalized partial regression analysis developed by Wright (1921), is useful. Therefore, in the present investigation, path coefficient analysis was used in order to obtain the details on the direct and indirect impact on the seed yield of the various morphological characters. Since the findings of the path coefficient analysis based on genotypic correlation in most characters were not much different from those obtained from phenotypic correlation, only the results based on the coefficient of phenotypic correlation are discussed here.

The critical estimation of path coefficient analysis (Table 4), in which diagonal values represented direct effects, indicates that the harvest index had the highest direct and positive effect (0.624) on seed yield per plant, followed by primary branches per plant (0.411), number of seeds per umbel (0.193), dry weight of umbel (0.190), plant height (0.169) number of umbellets per umbel (0.148), days to maturity (0.098), days taken to flowering (0.069) and dry weight of plant at harvest (0.045) Similarly, in the other hands the days to 50 per cent flowering $(-0.027)$ followed by number of umbels per plant (0.091), number of seeds per umbellet (-0.361) and test weight $(-0.129)$ had the negative straight effect on seed yield per plant of fennel varieties at phenotypic level. At genotypic level (Table 3), primary branches per plant had the highest direct and positive effect (0.908) on seed yield per plant, followed by harvest index (0.538), number of umbellets per umbel (0.378), number of seeds per umbel 
(0.225), dry weight of umbel (0.192), plant height (0.058), Similarly, in the other hands the secondary branches per plant (-0.314) followed by days to 50 per cent maturity ($0.048)$, days to maturity $(-0.005)$, number of umbels per plant (-0.080), number of seeds per umbellet (-0.332), dry weight of plant at harvest $(-0.248)$ and test weight $(-0.256)$ had the negative direct effect on yield of the seed per plant of fennel varieties. These findings are in harmony with the reports of Sefidan (2014) and Jeeterwal et al., (2015) whereas Cosge et al., (2009) reported positive and highest direct effect of test weight on seed yield in fennel.

\section{Indirect effect}

At genotypic level, it was observed that the plant height showed positive ancillary effect on seed yield through number of umbellets per umbel (0.284), number of primary branches per plant (0.232) and number of seeds per umbel (0.179)While, plant height showed negative ancillary effect on seed yield through number of seeds per umbellet (-0.277) and dry plant weight at harvest $(-0.111)$. The primary branches showed positive unintended effect on seed yield through harvest index(0.270) and umbellet per umbel (0.172). It also unveiled negative indirect effect on yield through secondary branches (-0.328) and dry weight of plant at harvest. Days taken to flowering depicted negative ancillary effect on seed yield per plant through harvest index $(-0.274)$ and number of umbellets per umbel $(-0.157)$. It also exhibited positive unintended effect on seed yield through secondary branches per plant. Number of umbels per plant depicted positive indirect effect on seed yield per plant through primary branches $(0.715)$ and harvest index (0.466).

Number of umbellets per umbel exerted positive indirect effect on seed yield through number of primary branches (0.412), harvest index (0.284) and number of seeds per umbel (0.223). It also exhibited negative indirect effect on seed yield through secondary branches per plant $(-0.178)$ and days taken to flowering (-0.104).Number of seeds per umbellet depicted positive indirect effect on seed yield per plant through number of umbellets per umbel (0.321) and primary branches per plant (0.297) Although, seeds per umbel showed negative indirect effect on seed yield through dry weight of plant at harvest ($0.150)$ and number of secondary branches ($0.139)$.

Number of seeds per umbel showed positive ancillary effect on yield of seed through primary branches per plant (0.404) and number of umbellets per umbel (0.374). It also exhibited negative ancillary effect on seed yield through number of seeds per umbel ($0.321)$, number of secondary branches ($0.168)$, dry weight of plant at harvest (-0.129) and days taken to flowering (-0.089). Dry weight of umbel depicted positive indirect effect on seed yield per plant through primary branches per plant (0.497), harvest index (0.440) and number of umbellets per umbel (0.226).while, exhibited negative indirect effect on seed yield through number of seeds per umbellets (-0.209) and dry weight of plant at harvest (-0.158), and number of secondary branches (-0.132). Harvest index recorded positive ancillary effect on yield of seed through primary branches per plant (0.456), number of umbellets per umbel (0.200) and dry weight of umbel (0.157). While, exhibited negative ancillary effect on seed yield through secondary branches per plant $(-0.165)$ and number of seeds per umbellet (-0.142). The test weight showed positive ancillary effect on seed yield through dry weight of plant at harvest (0.107), harvest index (0.036) and number of seeds per umbellet (0.091).

Direct effects were greater than indirect effects in path analysis and the change in 
either direction between the phenotypic and genotypic path coefficients was barely noticed. The path coefficient analysis found that through umbels per plant and seeds per umbel, which had the highest positive and important association with seed yield. The number of primary branches per plant, test weight and number of seeds per umbel also had high direct effect on seed yield per plant, whereas the number of umbellets per umbel had a poor and positive direct effect on seed yield per plant. The value of coefficient of interaction between a causal factor and the outcome is almost equal to its direct effect. Therefore, the true interrelation was clarified by correlations and indicated that a direct selection of these parameters would be efficient. This outcome is in line with previous studies of Idhol et al., (2009) in coriander.

\section{Residual effect}

The correlations and inter-correlations show that the fourteen causal traits explain much of variability for seed yield per plant. In fact, a residual effect of 0.160 , under phenotypic path analysis (Table 4) implies that the causal traits explained about 84.20 per cent of the variability in the seed yield per plant, leaving 15.80 per cent of the variability unexplained. While, 0.045in case of genotypic path study (Table 3) implies that the fundamental traits explained about 96.50per cent of the variability in the yield per plant of seed, leaving 4.50 per cent of the variability unexplained.

The results obtained from this research of character association and path coefficient analysis revealed that number of umbels per plant, harvest index, umbels per umbel, seeds per umbel, dry weight of umbelin positive direction and days taken to flowering in negative direction have significant influence on seed yield per plant in fennel. Thus, selection for these characters can be considered as important criteria in improving seed yield per plant in fennel.

\section{References}

Agnihotri, P., Dashora, S. L. and Sharma. R. K. 1997. Variability, correlation and path analysis in fennel (Foeniculum vulgar e Mill.). J. Spices Aromat. Crops, 6(1): 51-54.

Agrawal, P. C., Dev. U. and Rani. I. 2001. Fusarium species intercepted in exotic crop germplasm during 1976-99. Indian J. Agric. Sci., 71: 736-739.

Cosge. B., Ipek, A. and Gurbuz. B. 2009. Some phenotypic selection criteria to improve seed yield and essential oil percentage of sweet fennel (Foeniculum vulgare Mill var. Dulce). TarimBilimleriDergisi, 15(2): 127-133.

Garg. V. K., Shukla. S. and Singh, P. K. 2003. Genetic association in fennel grown on sodic soil. J. Spices Aromat. Crops. 12(2): 171-173.

Jeeterwal. R. C., Sastry. E. V. D., Rajput. S. S. and Singh, D. 2015. Genetic variability, character associations, path coefficient and divergence analysis in inbreds of fennel (Foeniculum vulgare Mill., Int. J. Seed Spices, 5(2): 51-53.

Kumar. R., Meena. R. S., Verma. A. K., Ameta. H., Panwar. A. 2017. Analysis of genetic variability and correlation in fennel (Foeniculum vulgare Mill.) germplasm. Agric. Res. Technol. Open Access J, 3(4): 1-5.

Meena. S. K., Singh. B. and Meena. A. K. 2013. Variability in fennel (Foeniculum vulgare Mill.) for yield and yield attributes. Indian Res. J. Genet. Biotech., 5(2): 117-124.

Rajput. S. S., Singhania, D. L., Singh. D., Sharma. K. C. and Rathore. V. S. 2004. Assessment of genetic variability in fennel (Foeniculum vulgare Mill). Published in National 
Seminar on New Perspective in Commercial Cultivation. Processing and Marketing of Seed Spices and Medicinal Plants held at S. K. N. College of Agriculture. Jobner (Rajasthan), pp. 10.

Rawat. S. K., Kumar. S. and Yadav. Y. C. 2013. Genetic evaluation for biometrical traits in fennel (Foeniculum vulgare Mill.), Spices Aromat. Crops, 22(1): 85-87.

Sefidan. A. Y., Valizadeh. M., Aharizad. S. and Sabzi. M. 2014. Path analysis of grain yield, some morphological traits and essential oil content in different fennel (Foeniculum vulgare Mill.) populations. J. Diversity Environ. Sci., 4(5): 10-15.

Shastry. E. V. D., Pareek. B. and Singh. D. 2009. Evaluation of SI progenies of fennel (Foeniculum vulgare Mill.). Published in National Workshop on "Spices and Aromatic Plants in 21st century India" held at S. K. N. College of Agriculture. Jobner (Rajasthan), pp. 48.

Yadav. P. S., Pandey. V. P. and Yadav. Y. 2013. Variability studies in fennel (Foeniculum vulgare Mill.). J. Spices Aromat. crops. 11(2): 203-208.

\section{How to cite this article:}

Ashfaq Anvarbadashalladli, K. M. Yuvaraj, R. Srinivasulu, M. Jayaprada and Deepthi Kiran, Y. 2020. Character Association and Path Analysis of Fennel (Foeniculum vulgare Mill.) Varieties in Rayalaseema Region of Andhra Pradesh. Int.J.Curr.Microbiol.App.Sci. 9(12): 3464-3478. doi: https://doi.org/10.20546/ijcmas.2020.912.412 